\title{
KINERJA PORTOFOLIO OPTIMAL PADA SAHAM BERBAGAI INDEKS DENGAN KALKULASI RASIO SORTINO, MODIGLIANI SQUARE, DAN ROY'S SAFETY FIRST
}

\author{
Baiq Nurul Suryawati ${ }^{1}$, Laila Wardani ${ }^{2}$, Sulaeman Sarmo ${ }^{3}$, Iwan Kusmayadi ${ }^{4}$ \\ ${ }^{1}$ Fakultas Ekonomi Universitas Mataram, bqsuryawati@gmail.com \\ ${ }^{2}$ Fakultas Ekonomi Universitas Mataram,elawardani.mtr@gmail.com \\ ${ }^{3}$ Fakultas Ekonomi Universitas Mataram, sarmo-sulaiman@yahoo.com \\ ${ }^{4}$ Fakultas Ekonomi Universitas Mataram, iwankusmayadi304@gmail.com
}

\begin{abstract}
The main purpose of this research is evaluating portfolio performance of variousindexes that comprises constituent index in Indonesia Stock Exchange. The performance of evaluation calculatesbasedon Sortino, Modigliani Square and Roy Safety First ratio. Hence, the difference between its portfolios performances will shows the significance of each market's differentite. The indexesare LQ 45, Jakarta Islamic Index (JII), Indeks Saham Syariah Indonesia, and BISNIS 27. The result shows that there is significance different between the share markets whereas the investment pattern of portfolio will represent investor's desired return. However, as the measurementrealize on adjusting return and risk, thus, it will necessary to enhance investor's with more pragmatic method such as share price volatility to persuade more investment. Share price volatility, furthermore, will give more precise information about how return created to profit investors.
\end{abstract}

Keywords: Indexes, Investment, Portfolio Mesurement, Sortino, Modigliani Square, Roy Safety First

\section{PENDAHULUAN}

Mardiyanto (2009) menjabarkan keberadaan tiga bagian mendasar yang menjadi akar dari ilmu manajemen keuangan, yaitu permasalahan yang terkait dengan keputusan pembiayaan (pendanaan)/financing, penanaman modal/investing, dan kebijakan dalam pemberian dividen (dividen policy). Selanjutnya, investasi ditengarai sebagai bagian paling produktif dimana ketepatan didalam keputusan investasi-lah yang akan menentukan kemakmuran bagi investor tersebut

Kendati demikian, berbagai upaya yang terkait dengan upaya memperoleh pendanaan, melakukan penanaman modal dan pemberian dividen bersifat komprehensif. Oleh karena, hal-hal tersebut harus dipahami dalam upaya mempelajari manajemen keuangan sebagai satu kesatuan.

Mengacu pada informasi sebelumnya, maka pasar modal adalah tempat yang paling ideal untuk mencari modal bagi perusahaan yang memiliki pengelolaan yang baik. Hal ini dikarenakan adanya aturan di pasar modal yang harus dipenuhi seperti: tercatat mampu memperoleh laba minimal selama kurang lebih tiga (3) tahun berturutturut; serta memiliki laporan keuangan yang terlaporkan/tercatat dengan baik (Panduan Pemodal, IDX). Oleh karena itu, pasar modal menciptakan peluang bagi para pencari modal dan pemberi modal. Lebih lanjut lagi, dapat dikatakan bahwa pasar modal adalah wahana untuk mengimplementasikan ilmu investasi.

Berinvestasi di pasar modal senyatanya memberikan pressure atau tekanan serta tuntutan untuk pengambilan keputusan yang cepat, terstruktur dan sejalan dengan mekanisme yang ada. Apalagi kenyataan adanya berbagai aplikasi mobile dari perusahaan sekuritas yang membantu berbagai macam transaksi ini, dapat membuat 
semua orang menjadi kewalahan (overwhelmed) dalam mengambil keputusan investasi. Hal ini menyebabkan sangat penting bagi setiap orang yang berkecimpung di dunia investasi untuk mengetahui bagaimana penilaian investasi yang sesungguhnya.

Kendati demikian, kenyataan yang ada di Indonesia, kita dapat melihat bahwa perkembangan pasar modal di Indonesia terkesan sangat lambat. Hal ini tercermin dari kecenderungan perubahan negatif dari beberapa indeks utama di Bursa Efek Indonesia.

Tabel 1. Indeks Konstituen Bursa Efek Indonesia per 13 Maret 2017

\begin{tabular}{|r|l|r|r|r|r|r|r|}
\hline No & \multicolumn{1}{|c|}{ Nama } & \multicolumn{1}{c|}{ Previous } & \multicolumn{1}{c|}{ High } & \multicolumn{1}{c|}{ Low } & \multicolumn{1}{c|}{ Last } & \multicolumn{1}{c|}{ Change } & \multicolumn{1}{c|}{$\begin{array}{c}\text { \% } \\
\text { Change }\end{array}$} \\
\hline 1 & COMPOSITE & 5409,372 & 5409,372 & 5386,348 & 5409,372 & 0,000 & 0,000 \\
\hline 2 & MBX & 1532,215 & 1532,142 & 1526,230 & 1529,722 & $-2,490$ & $-0,160$ \\
\hline 3 & KOMPAS100 & 1136,995 & 1136,673 & 1130,929 & 1134,398 & $-2,600$ & $-0,230$ \\
\hline 4 & LQ45 & 896,292 & 896,125 & 891,115 & 894,192 & $-2,100$ & $-0,230$ \\
\hline 5 & DBX & 858,525 & 858,443 & 848,837 & 858,004 & $-0,520$ & $-0,060$ \\
\hline 6 & JII & 697,270 & 697,640 & 692,908 & 695,129 & $-2,140$ & $-0,310$ \\
\hline 7 & INFOBANK15 & 631,995 & 633,907 & 629,297 & 631,995 & 0,000 & 0,000 \\
\hline 8 & IDX30 & 487,297 & 487,297 & 484,569 & 487,297 & 0,000 & 0,000 \\
\hline 9 & BISNIS-27 & 468,073 & 467,957 & 465,617 & 466,698 & $-1,380$ & $-0,290$ \\
\hline 10 & Investor33 & 377,000 & 377,044 & 375,533 & 375,881 & $-1,120$ & $-0,300$ \\
\hline 11 & PEFINDO25 & 370,261 & 370,760 & 367,690 & 370,020 & $-0,240$ & $-0,070$ \\
\hline 12 & SMInfra18 & 350,109 & 351,047 & 347,951 & 349,202 & $-0,910$ & $-0,260$ \\
\hline 13 & SRI-KEHATI & 318,131 & 318,204 & 316,978 & 318,131 & 0,000 & 0,000 \\
\hline 14 & MNC36 & 305,050 & 305,313 & 303,798 & 305,050 & 0,000 & 0,000 \\
\hline 15 & ISSI & 174,816 & 174,893 & 173,921 & 174,816 & 0,000 & 0,000 \\
\hline
\end{tabular}

Sumber: Bursa Efek Indonesia

Pasar Modal Indonesia atau pasar modal secara garis besar memberi kesempatan kepada setiap investor untuk membeli bisnis jadi pada dasarnya yang diperdagangkan di pasar modal adalah bisnis. Didalam investasi, diversifikasi atau keragaman pilihan dalam menentukan investasi memegang peran penting untuk memperoleh hasil yang optimal.

Hal diatas sejalan dengan kenyataan bahwa setiap pilihan investasi dari sebuah portofolio semestinya terukur kinerjanya. Pengukuran kinerja portofolio menjadi bagian penting yang dipelajari dalam manajemen keuangan khususnya yang berkaitan dengan investasi. Upaya melakukan pengukuran kinerja portofolio dilakukan untuk melihat kemampuan penyusunan portofolio yang merupakan penggabungan beberapa aset yang diindikasikan secara teoritis mampu menurunkan tingkat risiko dan dapat memberikan return atau hasil yang optimal.

Salah satu model dalam pembentukan portofolio optimal adalah Elton-GruberPadberg (EGP) Model. EGP (Elton-Gruber-Padberg, 1976) Model menyediakan sebuah model alternatif untuk memudahkan proses seleksi portofolio optimal. EGP model didasarkan pada kinerja saham melalui pendekatan reward-to-volatility (RVOL) yakni excess return dibagi systematic risk.

Selanjutnya, portofolio kemudian merupakan kajian yang menarik karena didalam penyusunan portofolio bukanlah hal yang mudah untuk menggabungkan atau mengkombinasikan aset sementara ada banyak pilihan dan kenyataan tidak transparansinya informasi dipasar. Selain itu ada kenyataan bahwa pasar akan sangat 
sulit untuk dikalahkan, tetapi bukannya tidak mungkin untuk melakukan pendekatanpendekatan yang bersifat ilmiah terkait hal ini. Untuk dapat melakukan koreksi terhadap penyusunan portofolio yang sudah dibuat maka upaya mengukur kinerja portofolio harus dilakukan, oleh karena itu, penelitian ini dimaksudkan untuk menelisik kajian ilmiah terkait dengan pengukuran kinerja portofolio dalam pasar modal yang ada di Indonesia sehingga dapat diperoleh gambaran yang lebih komprehensif.

\section{Perumusan Masalah}

Berdasarkan latar belakang yang sudah dipaparkan sebelumnya maka ada beberapa pertanyaan yang diangkat sebagai permasalahan dalam penelitian ini, yaitu:

1. Bagaimanakah mengukur kinerja portofolio optimal dengan model Elton Gruber Padberg pada berbagai indeks yang ada di Bursa Efek Indonesia dengan menggunakan kalkulasi rasio Sortino, Modigliani Square dan Roy's Safety First?

2. Apakah terdapat perbedaan yang signifikan antara pengukuran kinerja portofolio dengan model Elton Gruber Padberg pada berbagai indeks yang ada di Bursa Efek Indonesia dengan menggunakan kalkulasi rasio Sortino, Modigliani Square dan Roy's Safety First?

\section{TINJAUAN PUSTAKA}

\section{Pengertian Investasi}

Investasi adalah komitmen atas sejumlah dana atau sumber daya lainnya yang dilakukan pada saat ini, dengan tujuan memperoleh sejumlah keuntungan di masa yang akan datang. Seorang investor membeli sejumlah saham saat ini dengan harapan memperoleh keuntungan dari kenaikan harga saham ataupun sejumlah dividen di masa yang akan datang, sebagai imbalan atas waktu dan risiko yang terkait dengan investasi tersebut (Tandelilin, 2001:3).

Pada umumnya investasi dibedakan menjadi dua, yaitu investasi pada financial asset dilakukan di pasar uang, misalnya berupa sertifikat deposito, commercial paper, Surat Berharga Pasar Uang (SBPU) dan lainnya. Investasi juga dapat dilakukan di pasar modal, misalnya berupa saham, obligasi, warrant, opsi, dan lainnya. Sedangkan investasi pada real asset dapat dilakukan dengan pembelian aset produktif, pendirian pabrik, pembukaan pertambangan, perkebunan, dan lainnya (Huda, 2007:8)

\section{Dasar Keputusan Investasi}

Menurut Tandelilin (2001:6), dasar keputusan investasi dari tingkat return yang diharapkan, tingkat risiko, serta hubungan antara return dan risiko. Berikut ini akan dibahas masing-masing dasar keputusan investasi tersebut, yaitu:

1. Return. Alasan utama orang untuk berinvestasi adalah untuk memperoleh keuntungan. Return yang diharapkan investor dari investasi yang dilakukannya merupakan kompensasi atas biaya kesempatan (opportunity cost) dan risiko penurunan daya beli akibat adanya pengaruh inflasi. Dalam konteks manajemen investasi, perlu dibedakan antara return yang diharapkan (expected return) dan return yang terjadi (realized return). Return yang diharapkan merupakan tingkat return yang diantisipasi invetor di masa yang akan datang, sedangkan return yang terjadi atau return aktual merupakan tingkat return yang diperoleh investor pada masa lalu, antara tingkat return yang diharapkan dan tingkat return aktual yang 
diperoleh investor dari investasi yang dilakukan mungkin saja berbeda. Perbedaan antara return yang diharapkan dengan return yang benar-benar diterima (return aktual) merupakan risiko yang harus selalu dipertimbangkan dalam proses investasi. Sehingga dalam berinvestasi, disamping memperhatikan tingkat return, investor harus selalu mempertimbangkan tingkat risiko suatu investasi

2. Risiko, risiko bisa diartikan sebagai kemungkinan return aktual yang berbeda dengan return yang diharapkan. Dalam ilmu ekonomi pada umumnya, dan ilmu investasi pada khususnya terdapat asumsi bahwa investor adalah makhluk yang rasional. Investor yang rasional tentunya tidak akan menyukai ketidak-pastian atau risiko. Investor yang mempunyai sikap enggan terhadap risiko seperti ini disebut sebagai risk-averse investors. Investor seperti ini tidak akan mau mengambil risiko suatu investasi, jika investasi tersebut tidak memberikan harapan return yang layak sebagai kompensasi terhadap risiko yang harus ditanggung investor tersebut. Sikap investor terhadap risiko akan sangat tergantung kepada preferensi investor terhadap risiko. Investor yang lebih berani akan memilih risiko investasi yang lebih tinggi, yang diikuti oleh harapan tingkat return yang lebih tinggi pula. Demikian pula sebaliknya, investor yang tidak mau menanggung risiko yang terlalu tinggi, tentunya tidak akan bisa mengharapkan tingkat return yang terlalu tinggi.

3. Hubungan tingkat risiko dan return yang diharapkan. Hubungan antara risiko dan return yang diharapkan merupakan hubungan yang bersifat searah atau linier. Artinya semakin besar risiko suatu aset, semakin besar pula return yang diharapkan dari aset tersebut, demikian sebaliknya.

\section{Tujuan Investasi}

Menurut Tandelilin (2001:4) pada dasarnya tujuan orang melakukan investasi adalah untuk menghasilkan sejumlah uang. Tetapi tujuan investasi yang lebih luas adalah untuk meningkatkan kesejahteraan investor. Kesejahteraan dalam hal ini adalah kesejahteraan moneter, yang bisa diukur dengan penjumlahan pendapatan saat ini ditambah nilai saat ini dan pendapatan di masa datang. Secara lebih khusus, ada beberapa alasan mengapa seseorang melakukan investasi, antara lain adalah:

1. Untuk mendapatkan kehidupan yang lebih layak di masa yang akan datang. Seseorang yang bijaksana akan berfikir bagaimana meningkatkan taraf hidupnya dari waktu ke waktu atau setidaknya berusaha bagaimana mempertahankan tingkat pendapatannya yang ada sekarang agar tidak berkurang di masa yang akan datang.

2. Mengurangi tekanan inflasi. Dengan melakukan investasi dalam pemilikan perusahan, seseorang dapat menghindarkan diri dari risiko penurunan nilai kekayaan akibat adanya pengaruh inflasi.

3. Dorongan untuk menghemat pajak. Beberapa negara di dunia banyak melakukan kebijakan yang bersifat mendorong tumbuhnya investasi di masyarakat melalui pemberian fasilitas perpajakan kepada masyarakat yang melakukan investasi pada bidang-bidang usaha tertentu.

Untuk mencapai tujuan investasi, investasi membutuhkan suatu proses dalam pengambilan keputusan, seingga keputusan tersebut sudah mempertimbangkan ekspektasi return yang didapatkan dan juga risiko yang akan dihadapi. Menurut Sharpe (1995) dalam Huda (2007:9) pada dasarnya ada beberapa tahapan dalam pengambilan keputusan investasi antara lain:

1. Menentukan kebijakan investasi. Pada tahapan ini, investor menentukan tujuan investasi dan kemampuan/kekayaannya yang dapat diinvestasikan. Dikarenakan ada 
hubungan positif antara risiko dan return, maka hal yang tepat bagi investor untuk menyatakan tujuan investasinya tidak hanya untuk memperoleh banyak keuntungan saja, tetapi juga memahami bahwa ada kemungkinan risiko yang berpotensi menyebabkan kerugian. Jadi, tujuan investasi harus dinyatakan baik dalam keuntungan maupun risiko.

2. Analisis sekuritas. Pada tahapan ini berarti melakukan analisis sekuritas yang meliputi penilaian terhadap sekuritas secara individual atau beberapa kelompok sekuritas. Salah satu tujuan melakukan penilaian tersebut adalah untuk mengidentifikasi sekuritas yang salah harga (mispriced). Adapun pendapat lainnya mereka yang berpendapat bahwa harga sekuritas adalah wajar karena mereka berasumsi bahwa pasar modal efisien (Husnan, 2001 dalam Huda, 2007:9) dengan demikian pemilihan sekuritas bukan didasarkan atas kesalahan harga tetapi didasarkan atas preferensi risiko para investor, pola kebutuhan kas, dan sebagainya.

3. Pembentukan portofolio. Pada tahapan ketiga ini adalah membentuk portoolio yang melibatkan identifikasi aset khusus mana yang akan diinvestasikan dan juga menentukan seberapa besar investasi pada tiap aset tersebut. Di sini masalah selektivitas, penentuan waktu, dan diversifikasi perlu menjadi perhatian investor. Dalam investasi, investor sering melakukan diversifikasi dengan mengkombinasikan berbagai sekuritas dalam investasi mereka dengan kata lain investor membentuk portofolio. Selektivitas juga disebut sebagai micro-forecasting memfokuskan pada peramalan pergerakan harga saham biasa relatif terhadap sekuritas pendapatan tetap, misal obligasi perusahaan. Sedangkan diversifikasi meliputi konstruksi portofolio sedemikian rupa sehingga meminimalkan risiko dengan memperhatikan batasan tertentu.

4. Melakukan revisi portofolio. Pada tahapan ini, berkenaan dengan pengulangan secara periodik dari tiga langkah sebelumnya. sejalan dengan waktu, investor mungkin mengubah tujuan investasinya yaitu membentuk portofolio baru yang lebih optimal. Motivasi lainnya disesuaikan dengan preferensi investor tentang risiko dan return itu sendiri.

5. Evaluasi kinerja portofolio. Pada tahapan terakhir ini, investor melakukan penilaian terhadap kinerja portofolio secara periodik dalam arti tidak hanya return yang diperhatikan tetapi juga risiko yang dihadapi. Jadi, diperlukan ukuran yang tepat tentang return dan risiko juga standar yang relevan.

\section{Kategori Investor}

Menurut Huda (2007:11), secara garis besar tipikal investor terbagi menjadi 2 (dua) macam, tipikal yang berani mengambil risiko (risk taker) dan mereka yang tidak berani mengambil risiko (non-risk taker). Risk taker terbagi menjadi 3 bagian, yaitu:

1. Mereka yang berani mengambil risiko tinggi dengan harapan imbal hasil yang juga relatif tinggi (high risk for high return).

2. Mereka yang cukup berani mengambil risiko yang moderat dengan imbal hasil yang juga moderat (medium risk medium return).

3. Mereka yang hanya berani mengambil risiko dalam tingkat yang relatif rendah dengan imbal hasil yang juga relatif rendah (low risk low return).

Sedangkan menurut Halim (2003) dalam Huda (2007:12) memberikan definifsi untuk setiap tipe investor sebagai berikut:

1. Investor yang suka terhadap risiko (risk seeker). Merupakan investor yang apabila dihadapkan pada dua pilihan investasi yang memberikan tingkat pengembalian yang 
sama dengan risiko yang berbeda, maka ia akan lebih suka mengambil investasi dengan risiko yang lebih besar. Investor dengan karakter tersebut lebih cenderung bersikap agresif dan spekulatif dalam mengambil keputusan investasi.

2. Investor yang netral terhadap risiko (risk neutral). Merupakan tipikal investor yang meminta kenaikan tingkat pengembalian yang sama untuk setiap kenaikan risiko. Investor dengan karakter tersebut lebih cenderung bersikap hati-hati (prudent) dan fleksibel dalam mengambil keputusan berinvetasi.

3. Investor yang tidak suka terhadap risiko (risk averter). Merupakan tipikal investor yang apabila dihadapkan pada dua pilihan investasi yang memberikan tingkat pengembalian yang sama dengan risiko yang berbeda, maka ia lebih cenderung mengambil investasi dengan risiko yang lebih kecil.

\section{Risiko dalam Investasi}

Setiap keputusan investasi selalu menyangkut dua hal, yaitu risiko dan return. Risiko mempunyai hubungan positif dan linier dengan return yang diharapkan dari suatu investasi, sehingga semakin besar return yang diharapkan semkin besar pula risiko yang harus ditanggung oleh seorang investor. dalam melakukan keputusan investasi, khususnya pada sekuritas saham, return yang diperoleh berasal dari dua sumber, yaitu dividend dan capital gain, sedangkan risiko investasi saham tercermin pada variabilitas pendapatan (return saham) yang diperoleh (Huda, 2007:14).

Menurut Tandelilin (2001) dalam Huda (2007:15), dalam analisis tradisional, risiko total dari berbagai aset keuangan bersumber dari:

1. Interest rate risk. Risiko yang berasal dari variabilitas return akibat perubahan tingkat suku bunga. Perubahan tingkat suku bunga ini berpengaruh negatif terhadap harga sekuritas.

2. Market risk. Risiko yang berasal dari variabilitas return karena fluktuasi dalam keseluruhan pasar sehingga berpengaruh pada semua sekuritas.

3. Inflation risk. Suatu faktor yang mempengaruhi semua sekuritas adalah purchasing power risk. Jika suatu bunga naik, maka inflasi juga meningkat, karena lenders membutuhkan tambahan premium inflasi untuk mengganti kerugian purchasing power.

4. Business risk. Risiko yang ada karena melakukan bisnis pada industri tertentu.

5. Financial risk. Risiko yang timbul karena penggunaan leverage financial oleh perusahaan.

6. Liquidity risk. Risiko yang berhubungan dengan pasar sekunder tertentu dimana sekuritas diperdagangkan. Suatu investasi jika dapat dibeli dan dijual dengan cepat tanpa perubahan harga yang signifikan, maka investasi tersebut dikatakan liquid demikian pula sebaliknya.

7. Exchange rate risk. Risiko yang berasal dari variabilitas return sekuritas karena fluktuasi kurs currency.

8. Country risk. Risiko ini menyangkut politik suatu negara sehingga mengarah pada political risk.

\section{Pengukuran Evaluasi Kinerja Portofolio Optimal}

1. Metode Sortino. Metode ini hampir serupa dengan pengukuran yang dilakukan oleh metode Sharpe dengan dua perbedaan utama yaitu imbal hasil bebas risiko diganti dengan imbal hasil minimum yang diharapkan dan standar deviasi yang digunakan hanya standar deviasi dari imbal hasil portofolio yang berada dibawah imbal hasil 
minimum yang ditetapkan dimana dalam penelitian ini hasil minimum yang ditetapkan berasal dari nilai suku bunga Bank Indonesia. Tingkat suku bunga Bank Indonesia digunakan sebagai tingkat suku bunga bebas risiko. Besarnya minimal acceptable return (MAR) adalah tingkat suku bunga minimum yang diharapkan sebagai return oleh setiap investor dari investasi yang dilakukannya. Namun karena penelitian ini dilakukan terhadap portofolio secara umum bukan untuk suatu investor maka tingkat suku bunga Bank Indonesia digunakan sebagai MAR. Return yang berada dibawah MAR maka akan dianggap sebagai return yang tidak menguntungkan atau risiko dan return yng lebih besar dari MAR akan dikatakan sebagai return yang menguntungkan. Kelebihan dari Sortino adalah menggunakan standar deviasi dari imbal hasil dibawah imbal hasil minimum yang ditetapkan sebagai pembagi dan metode ini merupakan modifikasi dari metode Sharpe. Sortino lebih relevan kepada investor karena investor bebas untuk memilih patokan (imbal hasil minimum) yang paling cocok dengan tujuan mereka (Simforianus, 2008).

2. Modigliani Square. Merupakan variasi dari pengukuran populer yang telah dikenalkan sebelumnya. Seperti yang telah diketahui, indeks Sharpe dapat digunakan untuk meranking kinerja portofolio, tapi nilai numerikalnya tidak mudah untuk diinterpretasikan. Variasi ini diperkenalkan oleh Graham dan Harvey, kemudian dipopulerkan oleh Lea Modigliani dan Kakeknya Franco Modigliani, seperti Sharpe, $\mathrm{M}^{2}$ berfokus pada total risiko sebagai ukuran risiko, tetapi ukuran kinerja yang disesuaikan terhadap risiko secara sederhana diartikan sebagai perbedaan imbal hasil relatif terhadap indeks tolak ukur. $\mathrm{M}^{2}$ ratio merupakan pengukur kinerja portofolio optimal dengan mengkalkulasi excess return dari setiap unit dari total risiko (seperti Sharpe) tapi dengan tingkat standar deviasi yang sama dengan standar deviasi pasar. Caranya adalah portofolio yang ada (anggaplah semula bernama P) dicampur dengan investasi pada T-Bills/risk free assets dalam bobot tertentu sehingga terbentuk suatu portofolio (dinamakan $\mathrm{P}^{*}$ ) baru dengan tingkat standar deviasi yang sama dengan standar deviasi pasar. Perbedaan return yang terjadi antara return $\mathrm{P}^{*}$ terhadap return pasar menjadi alat ukur kinerja portofolio baru dengan arti yang lebih ekonomikal (Santosa, 2012).

3. Roy's Safety First ratio (atau disingkat dengan Roy's ratio) merupakan suatu teknik manajemen risiko dalam memilih portofolio investasi berdasarkan besarnya kemungkinan instrumen tersebut akan memberikan kinerja dibawah tingkat return yang diinginkan. Perhitungan Roy's ratio sangat sederhana dan hampir sama dengan metode Sharpe ratio yang selama ini umum dipergunakan. Perbedaannya dengan Sharpe Ratio adalah pada variabel return diinginkan. Pada Sharpe Ratio, variabel yang digunakan adalah Return Bebas Risiko seperti SBI, Deposito, sementara itu, pada Roy's Ratio, return diinginkan yang dipergunakan bersifat subjektif dalam besaran tertentu seperti $20 \%, 30 \%$ dst atau tingkat return sama dengan return pasar. Dari sisi interpretasi, hasil kedua perhitungan ini sama, semakin tinggi rasio yang dihasilkan, maka semakin optimal pula kinerja risiko dan return dari suatu portofolio (Rudiyanto, 2011).

\section{Tinjauan Penelitian Terdahulu}

Ada banyak penelitian yang telah dilakukan sebelumnya yang meneliti masalah perbandingan antara kinerja portofolio. Berikut adalah pemaparan penelitian-penelitian yang dianggap relevan dengan penelitian ini: 
1. Rachmayanti (2003) melakukan penelitian mengenai kinerja dari pembentukan portofolio saham-saham JII yang diteliti dan diamati dalam beberapa periode. Saham yang dipilih adalah yang benar-benar konsisten masuk kedalam JII. Tidak ada metode khusus yang diterapkan dalam pembentukan portfolio, karena portofolio yang dibentuk adalah fully replicated terhadap indeks yang menjadi benchmark. Adapun portofolio yang dibentuk tidak terfokus hanya kepada JII saja melainkan pada keseluruhan saham yang terkategori syariah dimana dalam hal ini Rachmayanti membentuk 45 saham syariah yang diambil dari DES sebagai bandingan dari LQ 45, hasil penelitian menunjukkan bahwa sharia screening process memberi impact positif terhadap konsistensi kinerja dari portofolio yang dibuat. Penelitian ini tidak membentuk portofolio berdasarkan metode tertentu yang biasa dikenal seperti SIM, MIM, atau CCM. Selain itu, dalam penelitiannya Rachmayanti menambahkan perlunya jangka waktu pengamatan yang lebih panjang (longer span time) mengingat pada saat diadakan penelitian JII relatif baru diperkenalkan. Berdasarkan hasil penelitian tersebut ditemukan bahwa pada tahun 2001 kinerja JII mengunguli kinerja LQ 45, tetapi pada tahun 2002 hal itu tidak terjadi. Menindak-lanjuti penelitian tersebut, ternyata hasil penelitian membuktikan bahwa secara konsisten 22 saham tandingan yang diambil dari DES menunjukkan konsistensi keunggulan kinerja dari pada saham konvensional yang juga merupakan salah satu implikasi dari dampak positif yang ditimbulkan oleh aplikasi penerapan shariascreening process.

2. Huda (2004) memperoleh temuan penelitian yaitu berdasarkan hasil kalkulasi terhadap beta dari saham-saham JII maka didapat temuan penelitian bahwa secara rata-rata untuk 30 emiten dalam JII di tahun 2002 memiliki rata-rata beta sebesar 0,80703 dan dikategorikan berisiko rendah. Sementara itu, untuk masa penelitian yang sama beta dari saham LQ 45 terhitung memiliki rata-rata sebesar 1,1308. Begitu juga pada tahun 2003, terdapat konsistensi, dimana beta saham-saham JII memiliki rata-rata sebesar 0,9092 sementara rata-rata saham beta yang masuk dalam LQ 45 mencapai 1,0996. Penelitian ini didisain untuk mengamati rata-rata beta dalam dua tahun pengamatan yaitu 2002 dan 2003.

3. Toni (2004) melakukan penelitian dengan membandingkan kinerja portofolio dalam rentang waktu 1 tahun yaitu sepanjang tahun 2003. Dua penemuan dari penelitian Toni (2004) adalah membagi kinerja portofolio dalam dua kategori yaitu: kinerja rata-rata dan kinerja kumulatif. Untuk penghitungan kinerja rata-rata dengan Indeks Sharpe, maka di tahun 2003, kinerja dari portofolio berbasis syariah dari sahamsaham JII menunjukkan outperform dibandingkan dengan portofolio konvensional dari saham-saham LQ 45. Selanjutnya kinerja kumulatif dibagi menjadi tiga kelompok, yaitu: kinerja harian, mingguan dan bulanan. Berdasarkan ketiga kelompok tersebut maka kinerja portofolio saham berbasis syariah pada kelompok JII menunjukkan outperform dibandingkan portofolio konvensional pada kinerja bulanan, sementara untuk harian dan mingguan menunjukkan kinerja yang tidak berbeda atau hampir sama.

4. Saad, et al (2010) penelitian yang dilakukan adalah berkenaan dengan perbandingan antara kinerja dari reksadana di Malaysia. Adapun tujuan dari penelitian ini untuk melakukan observasi terhadap efisiensi dari reksadana baik yang konvensional maupun yang berlandaskan syar'i dari tahun 2002 hingga 2005. Desain penelitian dilakukan dengan menggunakan Data Envelopment Analysis dengan melakukan pengukuran berdasarkan Malmquist index, yaitu membedakan efisiensi menjadi dua kategori yaitu efficiency change dan technical change index. Keterbatasan dari 
penelitian ini adalah unit analisis yang terbatas pada 5 reksadana yang menunjukkan bahwa hasil dari penelitian ini hanya menunjukkan indikasi dan bukan merupakan kesimpulan akhir yang sifatnya inconclusive. Temuan dari penelitian ini adalah dengan semakin besarnya ukuran dari sebuah reksadana maka kinerjanya menunjukkan indikasi menuju ketidak-efisienan.

5. Benjeoloun, et al (2009) penelitian yang dilakukan oleh Benjeleoun bertujuan untuk melakukan observasi sejauh mana diversifikasi dapat dilakukan pada Bursa Saudi Arabia. Adapun desain penelitiannya menggunakan model diversifikasi Statman, dan hasil penelitiannya menunjukkan bahwa biaya transaksi di Saudi Arabia sangat tinggi sehingga hasil penelitian menyarankan agar investor langsung berinvestasi pada pasar modal, tanpa melalui mutual fund atau lembaga reksadana. Selain itu penelitian ini juga menunjukkan bahwa dengan melakukan kombinasi lima aset secara random sudah cukup untuk memperoleh efisiensi dari diversifikasi.

\section{HIPOTESIS}

Ada dua (2) pertanyaan yang diajukan dalam penelitian ini pada rumusan masalah, namun, pertanyaan pertama bersifat deskriptif. Untuk hipotesis permasalahan yang kedua bersifat verifikatif, maka berdasarkan tinjauan pustaka dan kerangka pemikiran di atas dapat dirumuskan sebagai berikut:

"Diduga terdapat perbedaan yang signifikan antara metode pengukuran portofolio berdasarkan kalkulasi rasio Sortino, Modigliani Square dan Roy's Safety First pada berbagai kelompok indeks di Bursa Efek Indonesia"

\section{METODE PENELITIAN}

\section{Objek Penelitian}

Objek penelitian ini adalah saham-saham yang tercatat pada indeks terpilih yang terkategori dalam indeks konstituen, yaitu; LQ45; JII; ISSI dan BISNIS 27 selama tahun 2000-2016. Kemudian melakukan penghitungan dan penetapan portofolio optimal. Setelah melakukan perhitungan sehingga diketahui portofolio yang optimal dan yang dipilih kemudian melakukan penghitungan kinerja portofolio optimal berbagai kelompok indeks. Setelah melihat kinerjanya kemudian dilakukan perbandingan atau mengadakan komparasi dari tahun ke tahun atau per periode dengan jangka waktu 6 bulan sekali. Objek yang diamati dalam penelitian ini adalah rasio Sortino, Modigliani Square, dan Roy's SafetyFirst yang digunakan untuk mengukur kinerja portofolio berbagai kelompok indeks. Selain saham dari berbagai kelompok indeks konstituen yaitu LQ45; JII; ISSI dan BISNIS 27, objek penelitian lain yang juga diamati adalah SBI dan IHSG. 


\section{Desain Penelitian}

Metode penelitian yang digunakan adalah metode survey dengan analisis deskriptif verifikatif. Jenis penelitian yang dilakukan adalah deskriptif, yaitu penelitian yang dimulai dari pengumpulan data, mengolah, menyajikan hasil disertai interpretasi sehingga diperoleh gambaran yang jelas tentang pokok permasalahan yang diteliti.

\section{Operasionalisasi Variabel:}

Dalam penelitian ini variabel-variabel yang diteliti adalah:

1. Rasio Sortino dari masing-masing portofolio optimal indeks konstituen yaitu LQ45; JII; ISSI dan BISNIS 27 (SOR)

2. Rasio Modigliani Square dari masing-masing portofolio optimal indeks konstituen yaitu LQ45; JII; ISSI dan BISNIS $27\left(\mathrm{M}^{2}\right)$

3. Roy's Safety First Ratio dari masing-masing portofolio optimal indeks konstituen yaitu LQ45; JII; ISSI dan BISNIS 27 (Roy's)

4. Risk Free Rate (SBI/SWBI)

5. IHSG (Indeks Harga Saham Gabungan)

6. Varian dari rasio Sortino, Modigiani Square, dan Roy's Safety First $\left(\sigma^{2}\right)$

\section{Jenis, Cara Penentuan, dan Sumber Data/Informasi Jenis dan Cara Penentuan Data/Informasi}

Jenis data adalah data sekunder, berupa laporan pergerakan harga-harga saham bulanan yang termasuk dalam berbagai indeks terkategori indeks konstituen di Bursa Efek Indonesia, yaitu: LQ 45; JII; ISSI; dan BISNIS 27. Kurun waktu pengumpulan data yaitu selama periode Juli 2000 s/d Juli 2016 sebagai unit observasi. Setelah data dikumpulkan, kemudian data harga saham diolah, disusun dalam bentuk tabel. Penelitian ini disesuaikan dengan dikeluarkannya pengumuman perubahan indeks, yang umumnya dilakukan 2 kali dalam satu tahun. Pada setiap periode dilakukan evaluasi yaitu melakukan perbandingan antara kinerja portofolio kelompok saham dari berbagai indeks yang sudah dibentuk. Sebagai contoh, periode 1 mengumpulkan harga saham yang tercantum dalam daftar indeks LQ 45 selama Juli 2000 s/d Desember 2000 dan melihat bagaimana kinerjanya selama periode pengamatan. Berdasarkan data tersebut kemudian disusun portofolio optimal dengan menggunakan Model Elton Gruber Pardberg. Dalam analisis ini diasumsikan bahwa portofolio yang terbentuk tidak diinvestasikan, dengan demikian hanya dihitung return dan risiko historisnya. Selanjutnya, dilakukan penilaian kinerja dari masing-masing portofolio tersebut (hasil perhitungan historis). Hal yang sama berlaku untuk periode berikutnya.

Selanjutnya akan dilakukan pengukuran kinerja dengan kalkulasi rasio Sortino, Modigliani Square, dan Roy's Safety First dan kemudian dilakukan pembandingan. Perbedaan hasil yang kemungkinan akan muncul terjadi menunjukkan variasi kinerja portofolio yang dibentuk pada masing-masing indeks saham tersebut.

Mengingat kondisi portofolio setiap indeks berbeda, maka hasil yang didapat dari penelitian ini kiranya lebih tepat apabila jika dilakukan pada satu manajemen yang sama. Oleh karena asumsi dasar bahwa investasi yang dilakukan adalah mandiri, maka investor-lah yang akan menerapkan konsep manajerial yang sama terhadap kedua jenis investasi tersebut, dengan demikian kekhawatiran akan misleading akibat faktor tipe manajemen dan proses keputusan investasinya dapat disingkirkan.

Adapun data yang digunakan adalah data sekunder yang dikeluarkan oleh PT. BEI, data pergerakan saham dari berbagai indeks terkategori indeks konstituen, yaitu: 
LQ45; JII; ISSI dan BISNIS 27; IHSG dan data SBI/SWBI yang merupakan penanaman modal tanpa resiko (risk free rate, $\mathrm{R}_{\mathrm{f}}$ ).

\section{Sumber data}

Data yang diperlukan dalam penelitian diperoleh dengan melakukan survey kepustakaan, terdapat empat (4) indeks sebagai unit observasi pada kurun waktu penelitian 2000 s/d 2016. Data yang diambil bersumber dari dokumentasi dan laporanlaporan pergerakan saham yang masuk dalam berbagai indeks dari Indonesian Capital Market Directory (ICMD). Adapun kurun waktu data yang digunakan adalah selama periode Juli 2000 s/d Juli 2016.

\section{Prosedur Analisis Data}

Dalam membandingkan kinerja portofolio optimal saham berbagai indeks selama periode Juli 2000 sampai dengan Juli 2016, tahapan dalam melakukan analisis adalah sebagai berikut:

1. Pengumpulan data, berupa laporan periodik saham berbagai indeks dari Juli 2000 sampai dengan Juli 2016, data bulanan pergerakan saham selama periode penelitian, serta SBI/SWBI selama periode penelitian. Dalam penelitian ini yang menjadi objek penelitian adalah harga saham yang masuk ke dalam kelompok berbagai indeks, sedangkan dividen, biaya transaksi dan biaya lain serta pajak tidak diperhitungkan. Hal ini sejalan dengan asumsi Markowitz yang tidak memperhitungkan adanya transaction cost.

2. Berdasarkan data tersebut disusun portofolio optimal dengan menggunakan Model Elton Gruber Padberg. Portofolio yang terbentuk sesuai dengan daftar kelompok berbagai indeks, yaitu dimulai dari awal Januari dan awal Juli. Dalam analisis ini diasumsikan bahwa portofolio yang terbentuk tidak diinvestasikan, dengan demikian hanya dihitung return dan risiko historisnya. Selanjutnya, dilakukan penilaian kinerja dari masing-masing portofolio tersebut (hasil perhitungan historis) dengan menggunakan kalkulasi rasio Sortino, Modigliani Square, dan Roy's Safety First.

3. Berdasarkan hasil yang diperoleh akan menunjukan apakah investasi portofolio kelompok berbagai indeks menunjukkan superiority dan inferiority kinerja yang berbeda.

\section{Analisis Penentuan Portofolio Optimal Berbagai Kelompok Indeks}

Analisis ditujukan pada penyusunan portofolio optimal berbagai kelompok indeks di Bursa Efek Indonesia. Prosedur pengolahan data adalah:

1. Dipilih emiten yang tercatat dalam indeks terkategori indeks konstituen yaitu LQ45; JII; ISSI; dan BISNIS 27.

2. Data indeks harga masing-masing saham diolah untuk mencari expected return, dan risiko atau standar deviasi masing-masing saham.

3. Mencari expected return dan standar deviasi portofolio dengan menggunakan model Elton Gruber Padberg, dengan mencari:
a. Expected return masing-masing saham $\left(\mathrm{R}_{\mathrm{i}}\right)$
b. Expected return pasar $\left(\mathrm{R}_{\mathrm{m}}\right)$
c. Beta portofolio $\left(\beta_{\mathrm{P}}\right)$
d. Alpha portofolio $\left(\alpha_{\mathrm{p}}\right)$
e. Expected return portofolio $\left(\mathrm{E}\left(\mathrm{R}_{\mathrm{P}}\right)\right)$
f. Varian portofolio $\left(\sigma_{\mathrm{p}}^{2}\right)$ 
4. Mencari proporsi yang optimal dengan menggunakan Reward to Volatility

a. Mencari rasio Reward to Volatility (RVOL) untuk setiap saham yang dipilih, dan mengurutkannya dari $R V O L$ yang tertinggi hingga terendah

b. Menghitung cut-off rate masing-masing saham ( $\left.\mathrm{C}^{*}\right)$. Suatu saham akan dimasukkan dalam portofolio selama RVOL saham tersebut lebih besar daripada cut-off rate masing-masing saham. Berapa banyak saham yang dipilih bergantung pada unique cut-off rate $\mathrm{C}^{*}$. Semua saham dengan rasio yang lebih tinggi dari RVOL akan dimasukkan dan semua saham dengan rasio yang lebih rendah akan dikeluarkan. Pilihan yang terakhir akan menjadi Cut Off Rate C*

c. Setelah menentukan saham-saham yang dimasukkan dalam portofolio, kemudian ditentukan proporsi dana yang akan ditanamkan ke dalam masingmasing saham, sehingga terbentuk portofolio optimal. Hal ini dilakukan dengan menghitung $\mathrm{Z}$ masing-masing saham $\left(\mathrm{Z}_{\mathrm{i}}\right)$, kemudian $\mathrm{Z}_{\mathrm{i}}$ tersebut dijumlahkan. Untuk menghitung proporsi dana total digunakan hitungan $=\mathrm{Z}$ dibagi $\mathrm{Z}_{\mathrm{i}}$.

\section{Penghitungan Kinerja Portofolio Optimal dengan menggunakan kalkulasi rasio Sortino; Modigliani Square; dan Roy's Safety First}

Selanjutnya, melakukan penghitungan kinerja portofolio optimal berbagai indeks tersebut dengan menggunakan kalkulasi rasio Sortino; Modigliani Square; dan Roy's Safety First. Suatu portofolio dapat dikatakan lebih unggul terhadap semua pembandingnya jika memiliki risk premium yang tinggi dan atau risiko (beta atau standar deviasi) yang rendah.

1. Rasio Sortino, rasio ini merupakan sebuah modifikasi dari rasio Sharpe yang membedakan volatilitas berbahaya dari volatilitas umum dengan menghitung standar deviasi dari return aset negatif, yang disebut penyimpangan downside. Rasio Sortino mengurangi tingkat bebas risiko pengembalian portofolio, dan kemudian membagi dengan deviasi downside. Rasio Sortino yang besar menunjukkan ada probabilitas rendah kerugian besar. Hal ini dihitung sebagai berikut:

Dimana:

$$
\text { Sortino Ratio }=\frac{R_{\mathrm{a}}-\mathrm{R}_{\mathrm{f}}}{\sigma_{\mathrm{d}}}
$$

$\mathrm{R}_{\mathrm{a}}=$ Rata rata return portofolio selama periode pengamatan

$\mathrm{R}_{\mathrm{f}}=$ Rata rata tingkat return bebas risiko selama periode tertentu

$\sigma_{\mathrm{d}}=$ standar deviasi downside

Standar deviasi downside dapat dihitung dengan formula:

$\mathrm{DD}=\mathrm{Rpt}-\mathrm{MAR}$

$\mathrm{Rpt}=$ Return portofolio pada periode pengamatan

MAR = Minimum Acceptable Return yakni suku bunga bebas risiko

2. Rasio Modigliani Square, merupakan perluasan dari Sharpe ratio. M-Square rasio pada dasarnya diperoleh dari menghitung Sharpe ratio, kemudian, mengalikan hasil perhitungan Sharpe ratio dengan standar deviasi pasar (standar deviasi yang dihitung melalui return pasar). Perhitungan standar deviasi diperoleh dari menggunakan fungsi rumus Excel $(=\operatorname{stdev}(\ldots))$; stdev (return pasar)). Hasil yang telah diperoleh tersebut, ditambah dengan return bebas risiko (BI rate). Kinerja portofolio akan dibandingkan secara langsung dengan kinerja return pasar. Jika rasio $\mathrm{M}^{2} / \mathrm{M}$-Square positif maka kinerja portofolio adalah baik. Rumus rasio Modigliani Squre: 
dimana:

$$
M^{2}=\left(\left(\frac{R_{p}-R_{f}}{\sigma_{p}} \times \sigma_{m}\right)+R_{f}\right)-R_{m}
$$

$\mathrm{M}^{2}=$ Rasio Modigliani Square

$\mathrm{R}_{\mathrm{p}}=$ Return portofolio

$\mathrm{R}_{\mathrm{f}}=$ Return Risk Free

$\sigma_{\mathrm{m}}=$ standar deviasi pasar

$\sigma_{\mathrm{p}}=$ standar deviasi portofolio

$\mathrm{R}_{\mathrm{m}}=$ Return Market

3. Rasio Roy Safety First

Roy Safety First Ratio (atau disingkat dengan Roy's Ratio) merupakan suatu teknik manajemen risiko dalam memilih portofolio investasi berdasarkan besarnya kemungkinan instrumen tersebut akan memberikan kinerja dibawah tingkat return yang diinginkan. Perhitungan Roy's Ratio sangat sederhana dan hampir sama dengan Sharpe Ratio yang selama ini umum dipergunakan, yaitu:

$$
\text { Roy's Safety First Ratio }=\frac{E\left(R_{\mathrm{p}}\right)-\text { Return diinginkan }}{\sigma \mathrm{R}_{\mathrm{p}}}
$$

Dimana:

$\mathrm{E}\left(\mathrm{R}_{\mathrm{p}}\right)=$ Rata-rata return portofolio

$\mathrm{R}_{\mathrm{d}}=$ Return yang diinginkan investor

$\sigma \mathrm{R}_{\mathrm{p}}=$ Standar deviasi dari portofolio

\section{Pengujian Hipotesis}

Untuk menjawab hipotesis tersebut maka dilakukan pengujian terhadap variabel rasio Sortino (SOR), Modigliani Square $\left(\mathrm{M}^{2}\right)$, dan Roy's Safety First (Roy's) pada portofolio optimal kelompok saham berbagai indeks terkategori indeks konstituen. Pengujian hipotesis tersebut dilakukan dengan menjalankan prosedur MANOVA pada program SPSS, langkah-langkahnya adalah sebagai berikut:

Langkah-langkah yang dilakukan dalam menguji homogenitas varians sampel adalah sebagai berikut:

1. Menentukan varians sampel yang akan diuji:

Dalam penelitian ini, parameter yang akan diuji adalah SOR; $\mathrm{M}^{2}$, dan ROY's, dimana:

a. $\mathrm{SOR}=$ merupakan rasio Sortino sebagai alat ukur kinerja portofolio optimal berbagai kelompok indeks terkategori indeks konstituen yaitu: LQ45; JII; ISSI dan BISNIS 27.

b. $\mathrm{M}^{2}=$ merupakan rasio Modigliani Square sebagai alat ukur kinerja portofolio optimal berbagai kelompok indeks terkategori indeks konstituen yaitu: LQ45; JII; ISSI dan BISNIS 27.

c. ROY's= merupakan Roy's Safety First ratio sebagai alat ukur kinerja portofolio optimal berbagai kelompok indeks terkategori indeks konstituen yaitu: LQ45; JII; ISSI dan BISNIS 27.

2. Penentuan hipotesis, langkah ini dilakukan untuk menjawab masing-masing hipotesis yang telah diajukan, maka akan ada null hypothesis dan alternative hypothesis: 
$\mathrm{H}_{0}$ : SOR, $\mathrm{M}^{2}$, ROY's $=0$ (tidak terdapat perbedaan yang signifikan antara ukuran kinerja portofolio optimal berbagai kelompok indeks terkategori indeks konstituen, yaitu: LQ45; JII; ISSI dan BISNIS 27)

$\mathrm{H}_{\mathrm{a}}$ : SOR, $\mathrm{M}^{2}$, ROY's $\neq 0$ (terdapat perbedaan yang signifikan antara ukuran kinerja kelompok portofolio optimal dari berbagai kelompok indeks terkategori indeks konstituen, yaitu: LQ45; JII; ISSI dan BISNIS 27)

3. Penentuan taraf nyata (level of significance)

Dalam penelitian ini, taraf nyata yang digunakan adalah $\alpha=0,05=5 \%$

4. Penentuan statistik uji

Statsistik uji yang digunakan adalah uji $\mathrm{F}$, dimana:

dimana:

$$
\mathrm{F}_{\text {statistic }}=\frac{\mathrm{MS}_{\mathrm{B}}}{\mathrm{MS}_{\mathrm{W}}}
$$

$\mathrm{MS}_{\mathrm{B}}=$ Mean Square Between Groups

$\mathrm{MS}_{\mathrm{W}}=$ Mean Square Within Groups

5. Menentukan daerah kritis (critical area) dan titik kritis (critical point) serta daerah penerimaan $\mathrm{H}_{\mathrm{o}}$

a. Daerah kritis atau daerah penolakan $\mathrm{H}_{\mathrm{o}}$ adalah daerah dimana apabila $\mathrm{F}_{\text {statistic }}$ terletak di daerah ini akan menyebabkan $\mathrm{H}_{\mathrm{o}}$ ditolak.

b. Daerah penerimaan $\mathrm{H}_{\mathrm{o}}$ adalah daerah diluar daerah kritis, dimana apabila $\mathrm{F}_{\text {statistic }}$ terletak didaerah ini akan menyebabkan $\mathrm{H}_{\mathrm{o}}$ diterima.

6. Nilai titik kritis ditentukan oleh statistik uji yang digunakan yaitu, uji F:

Kriteria pengujian hipotesis adalah:

Jika $\mathrm{F}_{\text {statistic }} \leq \mathrm{F}_{\text {tabel, }}$, maka Ho diterima dan $\mathrm{H}_{\mathrm{a}}$ ditolak berarti Null Hypothesis diterima. Apabila Ho diterima berarti tidak terdapat perbedaan yang signifikan antara masing-masing parameter yang diuji, yaitu alat ukur kinerja portofolio optimal: rasio Sortino, Modigliani Square, dan Roy's Safety First dari masingmasing kelompok portofolio optimal berbagai indeks terkategori indeks konstituen yaitu: LQ45; JII; ISSI dan BISNIS 27.

Jika $\mathrm{F}_{\text {statistic }} \geq \mathrm{F}_{\text {tabel}}$, maka Ho ditolak dan $\mathrm{H}_{\mathrm{a}}$ diterima berarti Alternative Hypothesis diterima. Apabila Ho ditolak berarti terdapat perbedaan yang signifikan antara masing-masing parameter yang diuji, yaitu alat ukur kinerja portofolio optimal: rasio Sortino, Modigliani Square, dan Roy's Safety First dari masing-masing kelompok portofolio optimal berbagai indeks terkategori indeks konstituen yaitu: LQ45; JII; ISSI dan BISNIS 27.

\section{HASIL PENELITIAN DAN PEMBAHASAN}

Dari pembahasan pada bab sebelumnya indikator yang digunakan untuk melakukan evaluasi terhadap performa portofolio dalam penelitian ini adalah tiga metode, yaitu: Rasio Sortino, Roy's Safety First, dan M2. Sebagai indikator performa portofolio, ketiga rasio tersebut menggunakan standar deviasi sebagai alat ukur risiko yang menjadi denominator bagi return. Hal ini sejalan dengan penggambaran risiko sebagai suatu keseluruhan dengan menghitung baik risiko sistematis maupun nonsistematis yang ditanggung oleh investor. 
Sebagaimana diketahui pasar modal syariah dimulai ketika JII diperkenalkan pada 3 Juli 2000 bersamaan dengan dikenalkannya reksadana syariah. Sementara indeks LQ 45 telah lebih dulu diperkenalkan, dimana indeks ini terdiri dari 45 saham terbaik yang diperdagangkan di Bursa Efek Indonesia dengan tingkat kapitalisasi yang tinggi. Berbeda dengan JII dan LQ 45 yang merupakan kumpulan beberapa saham yang aktif diperdagangkan, ISSI yang diperkenalkan pada penghujung tahun 2007 merupakan keseluruhan saham yang dapat dikategorikan telah memenuhi syarat untuk dikategorikan sebagai saham syar'i.

\section{Perbandingan Pengukuran Untuk Kinerja Portofolio Pada Kelompok Saham JII,} Lq 45, Issi Dan Bisnis 27

Didalam analisis portofolio, evaluasi portofolio dilakukan dengan membandingkan tingkat return atau hasil yang diperoleh dengan tingkat risiko yang diukur dengan alat ukur yang berbeda-beda, seperti beta atau standar deviasi. Didalam periode observasi tahun 2000-2016 dapat dibandingkan pergerakan Rasio Sortino baik untuk kelompok JII, LQ 45, ISSI dan BISNIS 27.

Berikut grafik yang menggambarkan pergerakan Rasio Sortino untuk portofolio JII, LQ 45, ISSI dan BISNIS 27 untuk masa observasi 2000-2016:

Grafik 1. Pergerakan Rasio Sortino pada Portofolio JII, LQ 45, ISSI dan BISNIS 27 untuk periode observasi 2000-2016

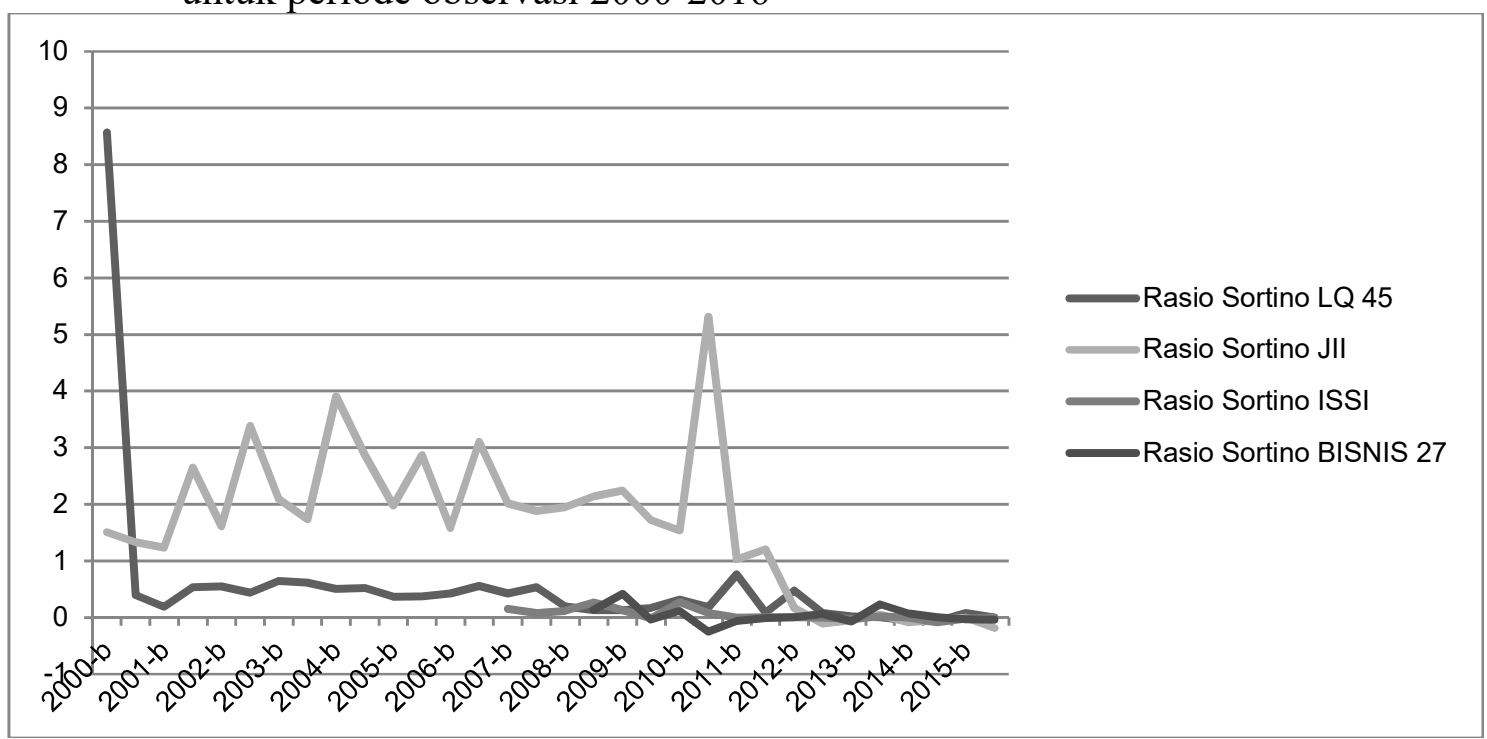

Sementara itu sejalan dengan pergerakan Rasio Sortino maka dapat dilihat pada grafik berikut pergerakan Rasio Modigliani Square dari portofolio JII, LQ 45, ISSI dan BISNIS 27. Rasio Modigliani Square menunjukkan volatilitas yang lebih tinggi dari pada Rasio Sortino untuk portofolio yang sama. 
Grafik 2. Pergerakan Rasio Modigliani Squre Portofolio JII, LQ 45, ISSI, dan BISNIS 27 untuk Periode Observasi 2000-2016

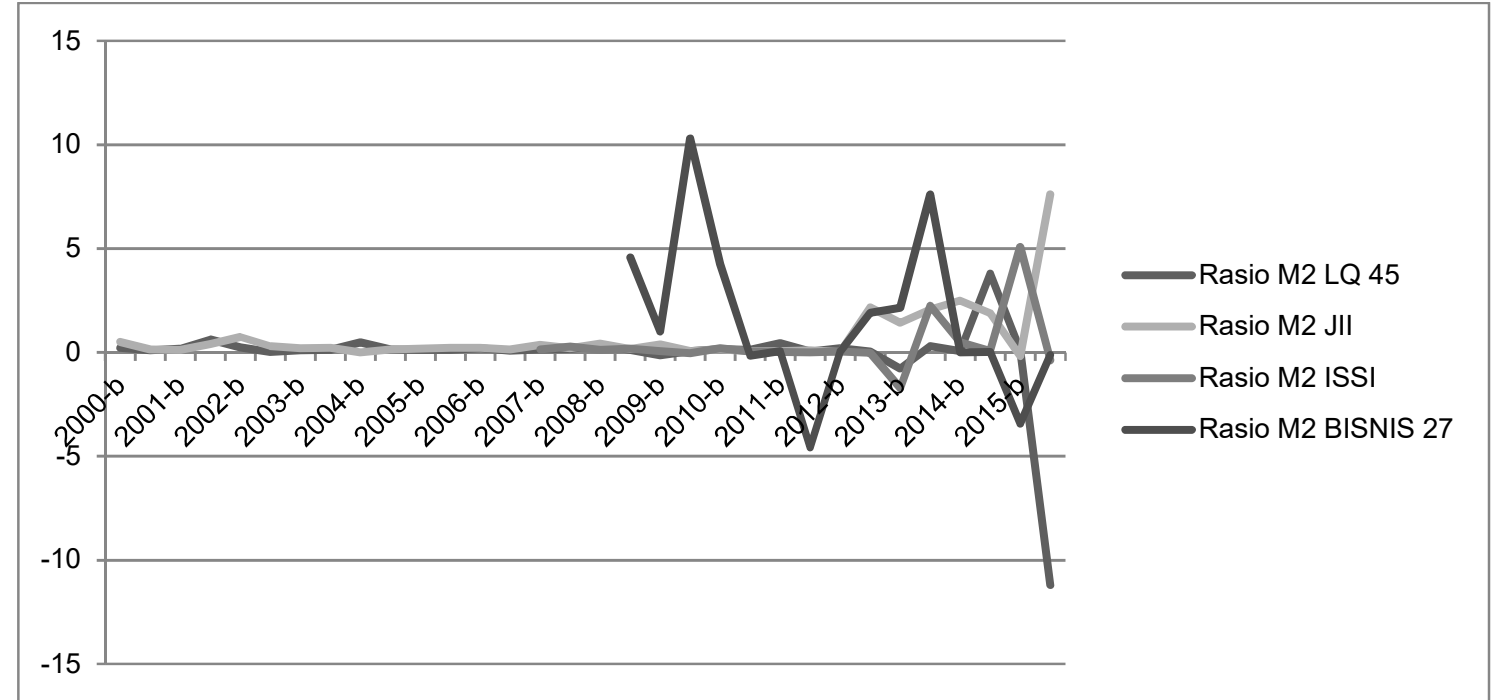

Selanjutnya akan ditampilkan pola yang berbeda dari pengukuran performa portofolio yang sama dengan menggunakan Rasio Roy's Safety First. Berdasarkan grafik, terlihat bahwa Rasio Sortiono memperlihatkan pergerakan yang lebih stabil dibandingkan dengan Rasio Modigliani Square, hal ini disebabkan karena nominator yang digunakan pada Rasio Modigliani Square adalah selisih rata rata Return Portofofolio dengan Risk Free Rate yang mencerminkan excess return yang secara terpisah dari kondisi pasar secara keseluruhan. Hal ini yang menyebabkan bentuk grafik yang juga mencerminkan volatilitas harga saham yang bersangkutan. Berikut adalah tabel yang menggambarkan pergerakan Rasio Roy’s Safety First untuk portofolio yang sama.

Grafik 3. Pergerakan Rasio Roy's Safety First pada Portofolio JII, LQ 45, ISSI, dan BISNIS 27 untuk Periode Observasi 2000-2016

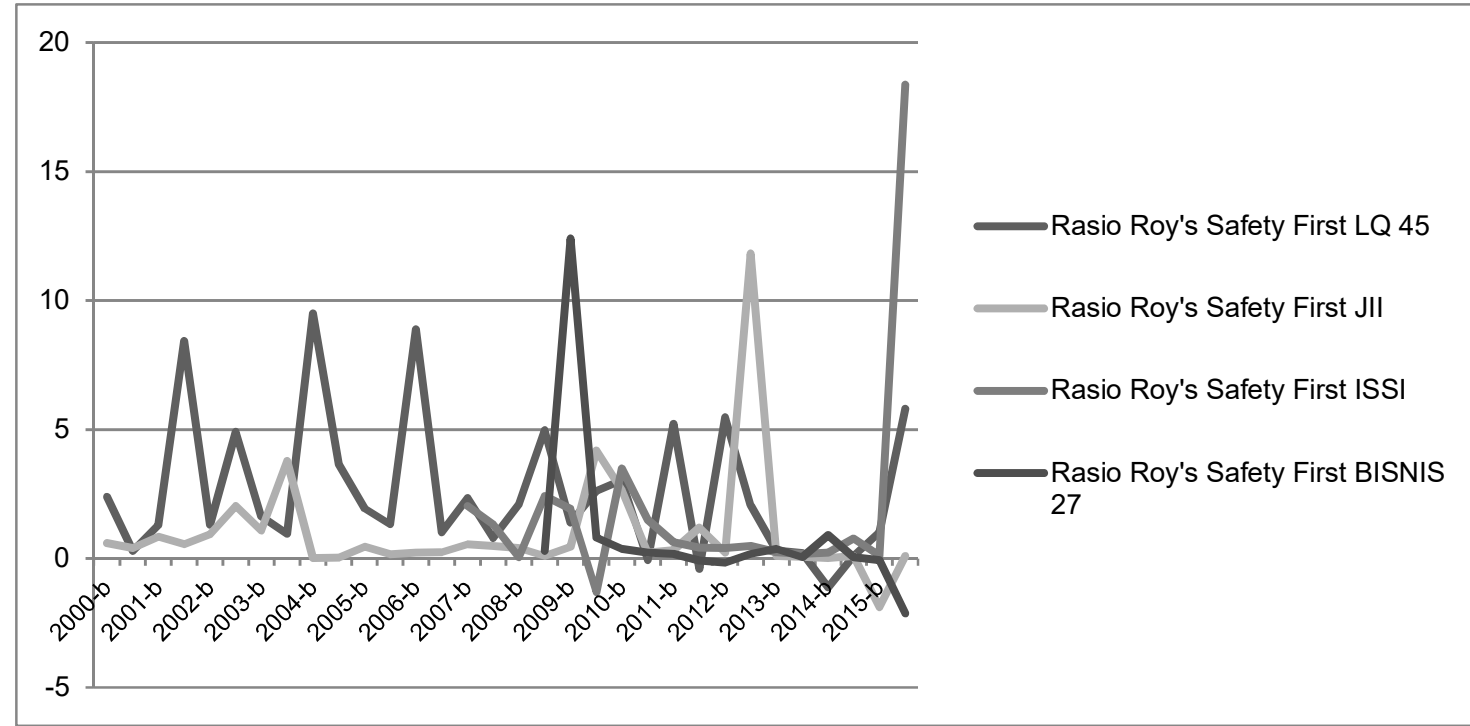

Portofolio dibentuk dengan menggunakan metode yang sama yaitu, Elton Pardberg Gruber Model. Komposisi mayoritas emiten yang masuk dalam portofolio JII bergerak di bidang : pertambangan, produsen otomotif, farmasi, telekomunikasi, pertanian-kehutanan dan perikanan, produsen semen, perumahan, dan lain-lain. Pada umumnya yang masuk ke dalam kelompok portofolio JII adalah usaha-usaha 
manufakturing skala besar, hal ini sejalan dengan konsep JII yang melakukan filtrasi perusahaan yang masuk ke dalam kategori ini bebas dari usaha yang dilarang dalam AlQuran seperti perbankan, rokok, persenjataan dan sebagainya.

Dengan adanya pembatasan ini maka performa portofolio-nya pun menunjukkan hasil yang lebih rendah dibandingkan saham-saham LQ 45. Seiring dengan perjalanan berkembangnya investasi syariah pada Bursa Efek Indonesia saat ini telah diperkenalkan ISSI (Indeks Saham Syariah Indonesia) sebagai benchmark pasar modal syariah di Indonesia. Selanjutnya akan dibahas prioritas portofolio saham-saham LQ 45, mayoritas saham-saham yang terjaring adalah emiten yang bergerak di bidang sektor perbankan, perusahaan tembakau/rokok, perusahaan otomotif, perusahaan pertambangan, dan lain-lain.

Sejalan dengan mayoritas emiten yang terjaring dalam portofolio, maka sesuai dengan pola grafik, hal ini disebabkan risiko yang ditimbulkan oleh emiten tersebut teridentifikasi memiliki volatilitas yang cukup tinggi terhadap perubahan harga pasar atau IHSG. Usaha-usaha yang bergerak dibidang finansial juga sangat rentan di akhir tahun 2007, terlebih setelah krisis keuangan melanda Amerika dan beberapa tahun setelahnya, krisis hutang finansial juga melanda kawasan Eropa seperti halnya yang terjadi di Yunani. Mengingat volatilitas yang tinggi dari beberapa saham pembentuk portofolio LQ 45 maka penurunan performa juga terjadi pada portofolio saham-saham ini.

Mereplikasi pola portofolio JII yang dominan pada usaha manufakturing maka, dapat dilihat titik berat dari saham-saham yang terjaring pada portofolio ISSI berkisar antara perusahaan perumahan, perusahaan pertambangan, perusahaan ritel, perusahaan makanan dan minuman, perusahaan otomotif, perusahaan telekomunikasi dan lain-lain. Dengan makin diperluasnya kesempatan untuk berinvestasi pada saham-saham syariah melalui diperkenalkannya ISSI (Indeks Saham Syariah Indonesia) di Bursa Efek Indonesia. Oleh karena itu, diversifikasi dari risiko yang ditunjukkan oleh penyebaran portofolio pada variasi perusahaan pun diharapkan dapat meminimasi tingkat risiko dari investasi.

Untuk memilih saham-saham yang akan menjadi kandidat dari portofolio maka yang dipilih hanya saham-saham yang menghasilkan return positif selama periode observasi. Selanjutnya, pembentukan portofolio dilakukan berdasarkan metode Elton Gruber Pardberg model untuk saham-saham yang tergabung dalam JII, LQ 45, ISSI dan BISNIS 27 selama periode observasi 2000-2016.

Pemilihan portofolio dengan menggunakan Elton Gruber Pardberg Modelpada kelompok saham-saham JII; LQ 45; ISSI dan BISNIS 27 merupakan pembentukan portofolio yang didasarkan atas pemeringkatan ranking RVOL (Reward to Volatility). Hal ini memberikan alternatif yang paling menguntungkan diantara pilihan yang ada. Lebih lanjut lagi hasil statistik deskriptif dari keseluruhan data dapat dilihat pada tabel dibawah ini:

Tabel 3. Statistik Deskriptif

\begin{tabular}{|l|l|r|r|r|}
\hline & \multicolumn{1}{|c|}{ Portofolio } & \multicolumn{1}{c|}{ Mean } & \multicolumn{1}{c|}{ Std. Deviation } & \multicolumn{1}{c|}{ N } \\
\hline \multirow{3}{*}{ SOR } & LQ 45 & .56780922 & 1.478305540 & 32 \\
\cline { 2 - 5 } & JII & 1.64628898 & 1.300259838 & 32 \\
\cline { 2 - 5 } & ISSI & .05426053 & .098333463 & 18 \\
\cline { 2 - 5 } & BISNIS 27 & .03614929 & .152727953 & 15 \\
\cline { 2 - 6 } & Total & .74608321 & 1.306127330 & 97 \\
\hline M2 & LQ 45 & -.09683006 & 2.138778553 & 32 \\
\hline
\end{tabular}




\begin{tabular}{|l|l|r|r|r|}
\hline \multicolumn{1}{|c|}{ Portofolio } & \multicolumn{1}{c|}{ Mean } & \multicolumn{1}{c|}{ Std. Deviation } & \multicolumn{1}{c|}{ N } \\
\hline \multirow{7}{*}{} & JII & .72135876 & 1.438554854 & 32 \\
\cline { 2 - 5 } & ISSI & .38254333 & 1.369898643 & 18 \\
\cline { 2 - 5 } & BISNIS 27 & 1.58002290 & 3.851462304 & 15 \\
\cline { 2 - 5 } & Total & .52135095 & 2.227201418 & 97 \\
\hline \multirow{3}{*}{ ROYS } & LQ 45 & 2.60927988 & 2.726753396 & 32 \\
\cline { 2 - 5 } & JII & 1.01746813 & 2.271131456 & 32 \\
\cline { 2 - 5 } & ISSI & 1.85113328 & 4.262687712 & 18 \\
\cline { 2 - 6 } & BISNIS 27 & .89469610 & 3.255325303 & 15 \\
\cline { 2 - 6 } & Total & 1.67831729 & 3.060341453 & 97 \\
\hline
\end{tabular}

Dari tabel diatas dapat dilihat rata-rata pengukuran performa portofolio LQ 45 memiliki nilai yang lebih baik dibandingkan dengan portofolio JII, ISSI, dan BISNIS 27. Hal ini menunjukkan bahwa kelompok LQ 45 menawarkan tingkat keuntungan yang lebih tinggi dibandingkan kelompok JII yang notabene menjadi proksi investasi syariah, akan tetapi harus juga dipertimbangkan aspek kesediaan investor didalam menanggung risiko. Kendati demikian dari data diatas dapat dilihat bahwa hasil performa dari portofolio optimal dari kelompok LQ 45 tidak jauh berbeda dari performa portofolio optimal dari kelompok JII. Sementara itu, kelompok ISSI adalah populasi dari saham syariah yang akan memperluas cakupan saham-saham yang akan terjaring dalam pembentukan portofolio sehingga performa yang diperoleh diharapkan meningkat.

Data pada tabel diatas juga menunjukkan bahwa adanya batasan-batasan yang diberlakukan pada saham-saham syariah ternyata memberikan batasan pula terhadap performa yang dihasilkannya. Sebagaimana yang telah disebutkan dalam annual report BEI di tahun 2008 krisis keuangan global yang melanda dunia memberi dampak buruknya performa beberapa bursa yang juga menyebabkan ditutupnya operasi bursa di berbagai belahan dunia. Analisis selanjutnya akan membahas uji statistik berkaitan dengan hipotesis yang sudah dibentuk dengan menggunakan alat analisis data Multivariate Analysis of Variance.

\section{Uji Perbandingan Antara Ketiga Measurement Performa Portofolio Saham Yang Terbentuk}

Sebelumnya telah diuraikan statistik deskriptif ketiga portofolio saham yang telah terbentuk. Melalui gambaran tersebut terlihat bahwa performa portofolio bentukan kelompok saham-saham LQ-45 lebih tinggi dibanding JII, ISSI maupun BISNIS 27, kendati hal ini juga semestinya mempertimbangkan tingkat risiko yang juga ditawarkan. Langkah selanjutnya adalah menguji hipotesis yang diajukan pada bab sebelumnya yaitu berkaitan dengan apakah terdapat perbedaan yang signifikan pada ketiga pengukuran performa portofolio syariah yang diproksi oleh JII dan ISSI, dengan portofolio konvensional yang diproksi oleh LQ 45 dan BISNIS 27.

Berikut adalah penjabaran hasil pengujian hipotesis penelitian berkaitan dengan signifikansi perbedaan pengukuran performa portofolio JII, LQ 45, ISSI dan BISNIS 27. 
Tabel 4. Hasil Uji Multivariat Perbandingan Performa Kelompok JII, LQ 45, ISSI dan BISNIS 27

\begin{tabular}{|c|c|c|c|c|c|c|c|c|c|}
\hline & ect & Value & $\mathbf{F}$ & $\begin{array}{l}\text { Hypothes } \\
\text { is df }\end{array}$ & $\begin{array}{c}\text { Error } \\
\text { df }\end{array}$ & Sig. & $\begin{array}{l}\text { Partial } \\
\text { Eta }\end{array}$ & $\begin{array}{l}\text { Noncent. } \\
\text { Paramete }\end{array}$ & $\begin{array}{c}\text { Observed } \\
\text { Power }^{\mathrm{d}}\end{array}$ \\
\hline Intercept & $\begin{array}{l}\text { Pillai's } \\
\text { Trace }\end{array}$ & .388 & $19.202^{b}$ & 3.000 & 91.000 & .000 & .388 & 57.607 & 1.000 \\
\hline & $\begin{array}{l}\text { Wilks' } \\
\text { Lambda }\end{array}$ & .612 & $19.202^{b}$ & 3.000 & 91.000 & .000 & .388 & 57.607 & 1.000 \\
\hline & $\begin{array}{l}\text { Hotelling's } \\
\text { Trace }\end{array}$ & .633 & $19.202^{b}$ & 3.000 & 91.000 & .000 & .388 & 57.607 & 1.000 \\
\hline & $\begin{array}{l}\text { Roy's } \\
\text { Largest } \\
\text { Root }\end{array}$ & .633 & $19.202^{b}$ & 3.000 & 91.000 & .000 & .388 & 57.607 & 1.000 \\
\hline Portofolio & $\begin{array}{l}\text { Pillai's } \\
\text { Trace }\end{array}$ & .371 & 4.368 & 9.000 & 279.00 & .000 & .124 & 39.314 & .998 \\
\hline & $\begin{array}{l}\text { Wilks' } \\
\text { Lambda }\end{array}$ & .657 & 4.647 & 9.000 & 221.62 & .000 & .131 & 33.368 & .991 \\
\hline & $\begin{array}{l}\text { Hotelling's } \\
\text { Trace }\end{array}$ & .482 & 4.802 & 9.000 & 269.00 & .000 & .138 & 43.214 & .999 \\
\hline & $\begin{array}{l}\text { Roy's } \\
\text { Largest } \\
\text { Root }\end{array}$ & .372 & $11.532^{\mathrm{c}}$ & 3.000 & 93.00 & .000 & .271 & 34.596 & .999 \\
\hline
\end{tabular}

Pada tabel diatas dapat dilihat keempat pengujian menunjukkan hasil yang signifikan, hal ini terlihat dari nilai signifikansi (sig.) keempat pengujian lebih kecil dari 0,05 . Dengan demikian maka pada tingkat kekeliruan 5\% diputuskan untuk menolak Ho dan menerima $\mathrm{Ha}$, sehingga dapat disimpulkan bahwa terdapat perbedaan antara pengukuran performa portofolio saham yang terbentuk. Setelah diketahui bahwa secara multivariate terdapat perbedaan yang signifikan pada ketiga pengukuran portofolio, selanjutnya dilakukan pengujian secara univariate untuk melihat apakah terdapat perbedaan pengukuran performa pada ketiga portofolio tersebut

Tabel 5. Rangkuman Hasil Uji Univariat Perbedaan Pengukuran Perfoma Ketiga Portofolio

\begin{tabular}{|l|l|r|r|r|r|r|r|r|r|}
\hline \multirow{2}{*}{ Source } & $\begin{array}{c}\text { Dependent } \\
\text { Variable }\end{array}$ & $\begin{array}{c}\text { Type III } \\
\text { Sum of } \\
\text { Squares }\end{array}$ & df & $\begin{array}{c}\text { Mean } \\
\text { Square }\end{array}$ & F & Sig. & $\begin{array}{c}\text { Partial } \\
\text { Eta } \\
\text { Squared }\end{array}$ & $\begin{array}{c}\text { Noncent } \\
\text { Paramet } \\
\text { er }\end{array}$ & $\begin{array}{c}\text { Observed } \\
\text { Power }\end{array}$ \\
\hline \multirow{2}{*}{$\begin{array}{l}\text { Corrected } \\
\text { Model }\end{array}$} & SOR & $43.124^{\mathrm{a}}$ & 3 & 14.375 & 11.080 & .000 & .263 & 33.241 & .999 \\
\cline { 2 - 10 } & M2 & $30.667^{\mathrm{b}}$ & 3 & 10.222 & 2.134 & .101 & .064 & 6.401 & .528 \\
\hline & ROYS & $51.458^{\mathrm{c}}$ & 3 & 17.153 & 1.882 & .138 & .057 & 5.646 & .473 \\
\hline \multirow{3}{*}{ Intercept } & SOR & 28.750 & 1 & 28.750 & 22.161 & .000 & .192 & 22.161 & .997 \\
\cline { 2 - 10 } & M2 & 36.233 & 1 & 36.233 & 7.563 & .007 & .075 & 7.563 & .777 \\
\cline { 2 - 10 } & ROYS & 219.842 & 1 & 219.842 & 24.120 & .000 & .206 & 24.120 & .998 \\
\hline \multirow{3}{*}{ Portofolio } & SOR & 43.124 & 3 & 14.375 & 11.080 & .000 & .263 & 33.241 & .999 \\
\cline { 2 - 10 } & M2 & 30.667 & 3 & 10.222 & 2.134 & .101 & .064 & 6.401 & .528 \\
\cline { 2 - 10 } & ROYS & 51.458 & 3 & 17.153 & 1.882 & .138 & .057 & 5.646 & .473 \\
\hline Error & SOR & 120.649 & 93 & 1.297 & & & & & \\
\cline { 2 - 10 } & M2 & 445.533 & 93 & 4.791 & & & & & \\
\cline { 2 - 10 } & ROYS & 847.648 & 93 & 9.114 & & & & & \\
\hline \multirow{2}{*}{ Total } & SOR & 217.767 & 97 & & & & & & \\
\cline { 2 - 10 } & M2 & 502.566 & 97 & & & & & & \\
\hline
\end{tabular}




\begin{tabular}{|c|c|c|c|c|c|c|c|c|c|}
\hline Source & $\begin{array}{c}\text { Dependent } \\
\text { Variable }\end{array}$ & $\begin{array}{l}\text { Type III } \\
\text { Sum of } \\
\text { Squares }\end{array}$ & df & $\begin{array}{l}\text { Mean } \\
\text { Square }\end{array}$ & $\mathbf{F}$ & Sig. & $\begin{array}{c}\text { Partial } \\
\text { Eta } \\
\text { Squared }\end{array}$ & $\begin{array}{l}\text { Noncent } \\
\text { • } \\
\begin{array}{c}\text { Paramet } \\
\text { er }\end{array}\end{array}$ & $\begin{array}{c}\text { Observed } \\
\text { Power }^{\mathrm{d}}\end{array}$ \\
\hline & ROYS & 1172.331 & 97 & & & & & & \\
\hline \multirow{3}{*}{$\begin{array}{l}\text { Corrected } \\
\text { Total }\end{array}$} & SOR & 163.773 & 96 & & & & & & \\
\hline & M2 & 476.201 & 96 & & & & & & \\
\hline & ROYS & 899.106 & 96 & & & & & & \\
\hline
\end{tabular}

Sebelumnya hasil pengujian secara multivariate menyimpulkan bahwa terdapat perbedaan yang signifikan secara simultan pada pengukuran performa dari ketiga portofolio yang terbentuk. Selanjutnya melalui hasil yang terdapat pada tabel diatas akan diuji lebih lanjut apakah secara terpisah/parsial terdapat perbedaaan diantara rasio Sortino sebagai alat ukur performa portofolio tersebut. Pada tabel dapat dilihat nilai $\mathrm{F}_{\text {hitungreturn }}$ sebesar 4.138 , dengan nilai signifikansi 0,021 . Karena nilai signifikansi lebih kecil dari 0,05 maka pada tingkat kepercayaan 95\% dapat disimpulkan terdapat perbedaan yang signifikan hanya pada Rasio Sortino sebagai alat ukur performa kelompok portofolio konvensional dan syariah.

Hasil uji univariate menunjukkan bahwa tidak terdapat perbedaan yang signifikan apabila portofolio diukur dengan menggunakan rasio Roy's Safety First dan Rasio Modigliani Square untuk berbagai kelompok indeks terkategori indeks konstituen. Uji post hoc selanjutnya dilakukan untuk melihat apakah perbedaan yang signifikan tersebut menunjukkan lebih kecil atau lebih besar tidak dapat dilakukan karena kelompok pengujian hanya terdiri dari dua kelompok, uji post hoc dapat dilakukan apabila terdapat tiga atau lebih grup/kelompok.

Sebelumnya hasil pengujian secara multivariate menyimpulkan bahwa terdapat perbedaan yang signifikan secara simultan pada ketiga kelompok portofolio yang terbentuk. Selanjutnya hasil univariate menunjukkan hanya rasio Sortino yang berbeda signifikan sementara lainnya tidak. Uji post hoc dilakukan untuk melihat apakah perbedaan yang signifikan tersebut menunjukkan lebih kecil atau lebih besar tidak dapat dilakukan karena kelompok pengujian hanya terdiri dari dua kelompok, uji post-hoc dapat dilakukan apabila terdapat tiga atau lebih grup/kelompok.

Tabel 6. Rangkuman Hasil Uji Post hoc Pada Ketiga Portofolio: JII, LQ 45, ISSI dan BISNIS 27

\begin{tabular}{|c|c|c|c|c|c|c|c|}
\hline \multirow{2}{*}{$\begin{array}{c}\text { Dependent } \\
\text { Variable }\end{array}$} & \multirow{2}{*}{\begin{tabular}{|c|} 
(I) \\
Portofoli \\
o \\
\end{tabular}} & \multirow[b]{2}{*}{$\begin{array}{c}(\mathbf{J}) \\
\text { Portofolio }\end{array}$} & \multirow{2}{*}{$\begin{array}{c}\text { Mean } \\
\text { Difference } \\
\text { (I-J) }\end{array}$} & \multirow[b]{2}{*}{ Std. Error } & \multirow[b]{2}{*}{ Sig. } & \multicolumn{2}{|c|}{ 95\% Confidence Interval } \\
\hline & & & & & & $\begin{array}{l}\text { Lower } \\
\text { Bound }\end{array}$ & $\begin{array}{l}\text { Upper } \\
\text { Bound }\end{array}$ \\
\hline \multirow[t]{12}{*}{ SOR } & \multirow[t]{3}{*}{ LQ 45} & JII & $-1.07847976^{*}$ & .284747687 & .000 & -1.64393223 & -.51302728 \\
\hline & & ISSI & .51354869 & .335578367 & .129 & -.15284344 & 1.17994082 \\
\hline & & $\begin{array}{l}\text { BISNIS } \\
27\end{array}$ & .53165993 & .356408872 & .139 & -.17609746 & 1.23941731 \\
\hline & \multirow[t]{3}{*}{ JII } & LQ 45 & $1.07847976^{*}$ & .284747687 & .000 & .51302728 & 1.64393223 \\
\hline & & ISSI & $1.59202845^{*}$ & .335578367 & .000 & .92563631 & 2.25842058 \\
\hline & & $\begin{array}{l}\text { BISNIS } \\
27\end{array}$ & $1.61013968^{*}$ & .356408872 & .000 & .90238230 & 2.31789707 \\
\hline & \multirow[t]{3}{*}{ ISSI } & LQ 45 & -.51354869 & .335578367 & .129 & -1.17994082 & .15284344 \\
\hline & & JII & $-1.59202845^{*}$ & .335578367 & .000 & -2.25842058 & -.92563631 \\
\hline & & $\begin{array}{l}\text { BISNIS } \\
27\end{array}$ & .01811124 & .398194525 & .964 & -.77262417 & .80884665 \\
\hline & \multirow{3}{*}{$\begin{array}{l}\text { BISNIS } \\
27\end{array}$} & LQ 45 & -.53165993 & .356408872 & .139 & -1.23941731 & .17609746 \\
\hline & & JII & $-1.61013968^{*}$ & .356408872 & .000 & -2.31789707 & -.90238230 \\
\hline & & ISSI & -.01811124 & .398194525 & .964 & -.80884665 & .77262417 \\
\hline
\end{tabular}




\begin{tabular}{|c|c|c|c|c|c|c|c|}
\hline \multirow[b]{2}{*}{$\begin{array}{c}\text { Dependent } \\
\text { Variable }\end{array}$} & \multirow{2}{*}{$\begin{array}{c}\text { (I) } \\
\text { Portofoli } \\
\text { o } \\
\end{array}$} & \multirow[b]{2}{*}{$\begin{array}{c}(\mathrm{J}) \\
\text { Portofolio }\end{array}$} & \multirow{2}{*}{$\begin{array}{c}\text { Mean } \\
\text { Difference } \\
\text { (I-J) }\end{array}$} & \multirow[b]{2}{*}{ Std. Error } & \multirow[b]{2}{*}{ Sig. } & \multicolumn{2}{|c|}{ 95\% Confidence Interval } \\
\hline & & & & & & $\begin{array}{l}\text { Lower } \\
\text { Bound }\end{array}$ & $\begin{array}{l}\text { Upper } \\
\text { Bound }\end{array}$ \\
\hline \multirow[t]{12}{*}{ M2 } & \multirow[t]{3}{*}{ LQ 45} & JII & -.81818882 & .547190694 & .138 & -1.90480109 & .26842345 \\
\hline & & ISSI & -.47937339 & .644870418 & .459 & -1.75995823 & .80121146 \\
\hline & & $\begin{array}{l}\text { BISNIS } \\
27 \\
\end{array}$ & $-1.67685296^{*}$ & 684899745 & .016 & -3.03692811 & -.31677780 \\
\hline & \multirow[t]{3}{*}{ JII } & LQ 45 & .81818882 & .547190694 & .138 & -.26842345 & 1.90480109 \\
\hline & & ISSI & .33881543 & 644870418 & .601 & -.94176942 & 1.61940028 \\
\hline & & $\begin{array}{l}\text { BISNIS } \\
27\end{array}$ & -.85866414 & .684899745 & .213 & -2.21873929 & .50141102 \\
\hline & \multirow[t]{3}{*}{ ISSI } & LQ 45 & .47937339 & .644870418 & .459 & -.80121146 & 1.75995823 \\
\hline & & JII & -.33881543 & .644870418 & .601 & -1.61940028 & .94176942 \\
\hline & & $\begin{array}{l}\text { BISNIS } \\
27 \\
\end{array}$ & -1.19747957 & .765 & .121 & -2.71701099 & .32205186 \\
\hline & \multirow{3}{*}{$\begin{array}{l}\text { BISNIS } \\
27\end{array}$} & LQ 45 & $1.67685296^{*}$ & .684899745 & .016 & .31677780 & 3.03692811 \\
\hline & & JII & .85866414 & .684899745 & .213 & -.50141102 & 2.21873929 \\
\hline & & ISSI & 1.19747957 & .765197922 & .121 & -.32205186 & 2.71701099 \\
\hline \multirow[t]{12}{*}{ ROYS } & \multirow[t]{3}{*}{ LQ 45} & JII & $1.59181175^{*}$ & .754755754 & .038 & .09301640 & 3.09060710 \\
\hline & & ISSI & .75814660 & .889488187 & .396 & -1.00820065 & 2.52449386 \\
\hline & & $\begin{array}{l}\text { BISNIS } \\
27\end{array}$ & 1.71458378 & .944701782 & .073 & -.16140673 & 3.59057429 \\
\hline & \multirow[t]{3}{*}{ JII } & LQ 45 & $-1.59181175^{*}$ & .754755754 & .038 & -3.09060710 & -.09301640 \\
\hline & & ISSI & -.83366515 & .889488187 & .351 & -2.60001240 & .93268211 \\
\hline & & $\begin{array}{l}\text { BISNIS } \\
27\end{array}$ & .12277203 & .944701782 & .897 & -1.75321848 & 1.99876254 \\
\hline & \multirow[t]{3}{*}{ ISSI } & LQ 45 & -.75814660 & .889488187 & .396 & -2.52449386 & 1.00820065 \\
\hline & & JII & .83366515 & .889488187 & .351 & -.93268211 & 2.60001240 \\
\hline & & $\begin{array}{l}\text { BISNIS } \\
27\end{array}$ & .95 & 351 & 367 & 49592 & 3.05237027 \\
\hline & \multirow{3}{*}{\begin{tabular}{|l|} 
BISNIS \\
27
\end{tabular}} & LQ 45 & -1.71458378 & .944701782 & .073 & -3.59057429 & 16140673 \\
\hline & & JII & -.12277203 & .944701782 & .897 & -1.99876254 & 1.75321848 \\
\hline & & ISSI & -.95643718 & 1.055459351 & .367 & -3.05237027 & 1.13949592 \\
\hline
\end{tabular}

Berdasarkan tabel Uji Post Hoc di atas dapat dilihat bahwa untuk pengukuran kinerja portofolio dengan menggunakan Rasio Sortino pada kelompok JII, LQ 45, ISSI dan BISNIS 27, hanya pengukuran pada LQ 45 dan ISSI yang menunjukkan signifikansi perbedaan mean difference sebesar 0.35 .

Hal ini menunjukkan keberartian perbedaan ukuran kinerja yang menunjukkan kinerja portofolio yang terbentuk dengan Elton Gruber Padber Model pada kumpulan saham akan memberikan hasil ukur yang lebih baik sebesar 1.59181175 apabila dibandingkan dengan portofolio yang terbentuk dari saham-saham yang tergabung dalam ISSI. Kendati sama dengan alat ukur kinerja lainnya yang menggunakan standar deviasi sebagai ukuran risiko, maka Modigliani Square yang menghitung risiko dengan membandingkan keberpengaruhan Return Pasar dan selisih Return Portofolio dengan Return Risk Free, dengan mengikut-sertakan pengaruh deviasi dari IHSG, menunjukkan bahwa tidak ada satu-pun yang signifikan di-antara perbedaaan tersebut, artinya meskipun ada perbedaan mean difference positif antara berbagai kelompok indeks terkategori indeks konstituen, perbedaan tersebut tidak menunjukkan keberartian yang nyata.

Jadi, berdasarkan ukuran kinerja Rasio Modigliani Square, baik portofolio yang terdiri dari kombinasi jumlah saham yang banyak seperti ISSI dan yang sedikit tidak berbeda. Apabila Rasio Sortino dan Rasio Modigliani Square mengacu pada Capital 
Market Theory, maka Roy's Safety First yang memperhitungkan kontribusi risk free asset terhadap return market sebagai implementasi dari Security Market Line (SML) menunjukkan bahwa mean difference yang positif dan menunjukkan superioritas portofolio konvensional terhadap syariah sebesar 1.515879210 adalah signifikan. Kinerja portofolio pada Roy's Safety First menunjukkan preferensi return dari investor, dimana kinerja portfolio yang baik akan ditunjukkan dengan nilai $\alpha$ yang positif. Dengan mengacu pada konsep SML, yang tidak lain merupakan intercept dari garis portofolio investasi. Hal ini menunjukkan kondisi ekuilibrium dimana semua portofolio diharapkan berada pada (berhimpit) dengan SML yang merupakan tingkat returnpasar. Namun, apabila terjadi penyimpangan, garis portofolio investasi akan berbeda dengan SML, dimana perbedaan itu disebut dengan differential returnyang menggambarkan perbedaan antara tingkat return portofolio investasi dengan tingkat return pasar. Differential return tersebut dilambangkan dengan $\alpha_{\mathrm{i}}$ dimana kinerja portofolio yang baik ditunjukkan dengan nilai $\alpha_{i}$ yang positif atau lebih.

Dari hasil serangkaian tes statistik terlihat dengan jelas kinerja yang dibentuk dari kumpulan saham LQ 45 selalu menunjukkan kinerja yang lebih baik dari kelompok saham terkategori indeks konstituen lainnya. Hal ini disebabkan pembentukan portofolio yang dilakukan dengan menggunakan Elton Gruber Pardberg Model hanya memberikan hasil optimum satu kemungkinan kombinasi portofolio, yang tidak memungkinkan adanya pilihan portofolio lain. Portofolio ini dibentuk berdasarkan penelitian yang dilakukan Friend, Blume, dan Crockett (2000), penelitian tersebut membandingkan kinerja portofolio reksadana (mutual fund) terhadap portofolio yang dibentuk secara acak, dengan menggunakan variance sebagai proxy risiko. Hasil dari penelitian tersebut menunjukkan bahwa rata-rata returnportofolio yang dibentuk secara acak selalu lebih tinggi dari rata-rata returnportofolio reksadana.

Pemilihan saham sebagai pembentuk portofolio tersebut sangat berpengaruh terhadap kemampuan alat ukur kinerja yaitu Rasio Sortino, Rasio Modigliani Square, dan Rasio Roy's Safety First karena alat ukur tersebut menggunakan parameter return dan risiko sebagai penentu ukuran kinerja. Hal ini memberi indikasi bahwa permodelan dalam pembentukan portofolio juga menjadi kunci utama bagi penelitian selanjutnya untuk dapat mengungkapkan perilaku investasi di pasar modal berdasarkan aliran gain dan loss yang menunjukkan nilai investasi yang sesungguhnya.

Mengacu pada hasil diatas juga dapat dilihat bahwa penambahan objek observasi dengan menambah satu kelompok, yaitu ISSI, sebagai kelompok yang mewakili populasi dari saham syariah, ternyata memiliki andil besar terhadap signifikansi uji hipotesis. Penambahan kelompok ISSI memperlihatkan bahwa hingga saat ini superioritas dari pasar konvensional teruji, artinya bahwa meskipun dengan kelompok populasi dari seluruh saham khusus dengan banyak batasan seperti kategori syariah, apabila investor mengacu pada portofolio theory dimana hanya satu model kombinasi portofolio optimal yang mungkin diambil dari serangkaian pilihan, maka pasar konvensional selalu lebih baik. Di lain pihak, serangkaian tes statistik juga membuktikan bahwa perbedaan yang terjadi adalah signifikan atau nyata. Berdasarkan pada kedua hasil tersebut, kembali lagi kepada investor, bahwa pasar modal syariah sebagai bagian indeks konstituen yang ditawarkan sebagai alternatif investasi bagi yang ingin berinvestasi dalam tata kaidah syar'i sehingga tujuan investasi tersebut yang semestinya dikedepankan. 


\section{KESIMPULAN}

Berdasarkan hasil penelitian dan pembahasan kinerja portofolio dengan rasio Sortino, Modigliani Square dan Roy Safety First dari saham-saham dalam berbagai indeks konstituen, yaitu LQ 45, Jakarta Islamic Index (JII), Indeks Saham Syariah Indonesia (ISSI), dan BISNIS 27 dapat ditarik kesimpulan sebagai berikut:

1. Mengacu pada hasil uji statistik dengan menggunakan MANOVA, terdapat perbedaan yang signifikan antara kinerja berbagai portofolio yang dibentuk berdasarkan pengelompokan indeks konstituen.

2. Setiap investor kembali lagi dihadapkan kepada pilihannya masing-masing di dalam menanamkan modalnya terkait pemilihan saham yang ditawarkan berbagai indeks konstituen di Bursa Efek Indonesia. Pemilihan saham dengan berbagai ppola portofolio dapat diterapkan untuk tujuan memperoleh keuntungan atau return yang diinginkan.

\section{DAFTAR PUSTAKA}

Benjelloun, Hicham, et all, 2009, Index Funds and Diversification in Saudi Arabia, International Journal of Islamic and Middle Eastern Finance and Management, Vol. 2, No. 3, pp. 201-212

De Bondt, Warner, et all, 2008, Behavioral Finance: Quo Vadis?, Journal of Applied Finance, 2008, pg.7

Derigs, Ulrich, et all, 2008, Review and Analysis of Current Shariah-Compliant Equity Screening Practices, International Journal of Islamic and Middle Eastern Finance and Management, Vol. 1, No. 4, pp. 285-303

Elton, E.J., et all, 1995, Modern Portfolio Theory and Investment Analysis, NY: John Wiley and Sons

Farrell Jr, James L, 1997, Portfolio Management Theory \& Application-International Edition, Singapore: Mc Graw Hill

Huda, Nurul, 2003, Pasar Modal Syariah dan Faktor yang Mempengaruhi Beta Saham (Studi Kasus JII dan LQ 45 Tahun 2002-2003), PSKTTI: FEUI

Jogiyanto, Hartono, 2009, Teori Portofolio dan Analisis Investasi, LPFE UGM

Mardiyanto, Handono, 2009, Inti Sari Manajemen Keuangan: Teori, Soal dan Jawaban, Jakarta : PT. Grasindo

Mohd. Yusof, et all, 2008, Towards an Islamic International Financial Hub: The Role of Islamic Capital Market in Malaysia, International Journal of Islamic and Middle Eastern Finance and Management, Vol. 1, No. 4, pp. 313-329 
Md. Saad, Norma, et all, 2010, A Comparative Analysis of The Kinerjance of Conventional and Islamic Unit Trust Companies in Malaysia, International Journal of Managerial Finance, Vol. 6, No. 1, pp. 24-47

Rachmayanti, T. Farida, 2003, Analisis Kinerja Portofolio Saham Syariah, Thesis PSKTTI, Universitas Indonesia

Rudiyanto, 2011, Mengenal Roy Safety First Ratio, http://rudiyanto.blog.kontan.co.id, diakses 13 Maret 2017, 5:28 PM

Santosa, Magdalena, et all, 2012, Penilaian Kinerja Produk Reksadana dengan Menggunakan Metode Perhitungan Jensen Alpha, Sharpe Ratio, Treynor Ratio, $\mathbf{M}^{2}$, dan Information Ratio, Jurnal Manajemen, Vol. 12, No. 1, pp. 63-76

Shah Bin, Mohd. Dali Nuardli Ridzwan Shah, et all, 2008, Kinerjance of Shariah Compliance Companies in The Plantation Industry, International Journal of Islamic and Middle Eastern Finance and Management, Vol. No.22, pp. 166-178

Simforianus; Yanthi Hutagaol, 2008, Analisis Kinerja Reksa Dana Saham dengan Metode Raw Return, Sharpe, Treynor, Jensen dan Sortino, Journal of Applied Finance and Accounting Vol. 1 No. 1, pp. 193-226

Tandelilin, Eduardus, 2010, Portofolio dan Investasi: Teori dan Aplikasi, Kanisius

Toni, Alfiyan, 2004, Analisis Perbandingan Kinerja Portofolio (Studi Kasus: Indeks Syariah dan Indeks Konvensional), Jakarta : PSKTTI-FE UI 